\title{
Pemasaran, Daya Tarik Ekowisata dan Minat Berkunjung Wisatawan
}

\author{
Kurniawan Gilang Widagdyo \\ Fakultas Ekonomi Universitas Sahid Jakarta \\ kurniawangilang@yahoo.com
}

\begin{abstract}
This research aims to analyze the potential of ecological tourism interest in Cipta Gelar Traditional Village West Java Indonesia and determine interest factors that have implication on visit intention domestic visitors. This research used survey, observation and indepth interview of stakeholders. Factor analysis used to analize interest factors toward ecological tourism that have implication on visit intention of domestic visitors. Three factors was formed there are Adventure and Culture factors, Tourism Interest and Natural Beauty, and History and Social Values. From those three factors, it is only factor 1 and 3 that imfluence on visit intention with correlation value among factors more than 0,5 there are 0,641 and 0,705. Meanwhile, factor 2 has value less than 0,5 that is 0,402. It has correlation with another factors that is not included in this research.
\end{abstract}

Keywords: ecological tourism, marketing, tourism interest factors

\begin{abstract}
Abstrak
Penelitian ini bertujuan mengetahui potensi daya tarik ekowisata di Kampung Adat Kasepuhan Ciptagelar Jawa Barat Indonesia dan menentukan faktor-faktor daya tarik ekowisata yang berimplikasi dalam meningkatkan pangsa pasar wisatawan domestik. Penelitian ini menggunakan metode survey dan observasi serta wawancara mendalam kepada para pemangku kepentingan. Metode analisis faktor digunakan untuk menganalisis faktor-faktor daya tarik ekowisata yang terdapat di kawasan Kampung Adat Kasepuhan Ciptagelar yang dapat meningkatkan pangsa pasar wisatawan domestik. Faktor-faktor yang terbentuk adalah: Faktor Petualangan dan Budaya, Faktor Daya Tarik Wisata dan Keindahan Alam serta Faktor Nilai Pranata Sosial dan Sejarah. Dari ketiga faktor terbentuk hanya faktor 1 dan 3 yang mempengaruhi minat berkunjung dan dapat meningkatkan pangsa pasar wisatawan domestik karena memiliki nilai korelasi antar faktor diatas 0,5 yaitu 0,641 dan 0,705. Sedangkan faktor 2 memiliki nilai lebih kecil dari 0,5 yaitu 0,402 dikatakan belum tepat dikarenakan faktor ini masih memiliki korelasi dengan variable lainnya yang tidak diteliti dalam penelitian ini.
\end{abstract}

Kata Kunci: ekowisata, pemasaran, minat berkunjung wisatawan

Diterima: 18 April 2017; Direvisi: 30 Mei 2017; Disetujui: 11 Juni 2017 


\section{PENDAHULUAN}

Kabupaten Sukabumi merupakan salah satu Kabupaten di Selatan Provinsi Jawa Barat yang memiliki segudang potensi pariwisata untuk dijelajahi. Wilayah yang memiliki luas $4.128 \mathrm{~km}^{2}$ memiliki kekayaan alam berupa GURILAPSS (Gunung, Rimba, Laut, Pantai, Sungai, Seni Budaya), hal ini merupakan sebuah ungkapan yang menggambarkan kekayaan potensi pariwisata Kabupaten Sukabumi, baik berupa daya tarik wisata wisata alam maupun wisata buatan.

Kawasan wisata berbasis budaya belum menjadi destinasi wisata unggulan didalam pengembangan industri kepariwisataan di Kabupaten Sukabumi. Daerah yang syarat akan budaya dan berbasis masyarakat tersebut adalah Kampung Adat Kasepuhan Ciptagelar, sebuah Kampung Adat yang berada di wilayah dusun Sukamulya, desa Sirnaresmi, kecamatan Cisolok, kabupaten Sukabumi yang memiliki keunikan dan keindahan yang berbeda dari tempat wisata lainnya. Ciri khas dari kawasan ini yakni dalam lokasi, bentuk rumah adat yang unik menyerupai lumbung padi, serta adat dan tradisi yang masih dipegang kuat oleh masyarakat pendukungnya yang diturunkan sejak 640 tahun yang lalu.

Lokasi Kampung Adat Kasepuhan Ciptagelar berada di wilayah Gn. Halimun, kampung ini memiliki lansekap hamparan sawah padi yang mengelilingi perkampungan, bentuk rumah adat yang unik, serta tradisi yang masih dipegang kuat oleh masyarakat kasepuhan membuat lokasi ini patut dikunjungi wisatawan. Terletak diantara lembah pegunungan Halimun, warga Kasepuhan adalah masyarakat yang bersandar pada budi daya padi. Bagi warga kasepuhan, bertani merupakan kewajiban hidup mereka.

Selain itu satu hal yang perlu menjadi perhatian adalah masih minimnya kajian akademik yang komprehensif berkaitan dengan konsep Community Based Sustainable Tourism Development di Kampung Adat Kasepuhan Ciptagelar. Oleh sebab itu penelitian ini mencoba untuk mengangkat konsep Ecotourism sebagai sebuah konsep pariwisata yang yang paling ideal untuk diterapkan dikawasan ini, hal ini mengacu kepada karakteristik kawasan Kampung Adat Kasepuhan Ciptagelar yang saat ini sudah memiliki hubungan yang harmonis dan dinamis dengan alam yang terwujudkan dari nilai-nilai kearifan lokal yang masih dipegang teguh oleh masyarakatnya hingga saat ini. Perlu dilakukan identifikasi daya tarik ekowisata 
serta bagaimana implikasinya terhadap minat wisatawan domestik untuk berkunjung ke Kampung Adat Kasepuhan Ciptagelar. Adapun tujuan dari penelitian ini adalah melakukan identifikasi faktor-faktor Daya Tarik dan mengetahui faktorfaktor yang berimplikasi terhadap minat berkunjung wisatawan domestik ke Kampung Adat Kasepuhan Ciptagelar.

Undang-undang RI nomor 10 tahun 2009, menjelaskan bahwa wisata adalah kegiatan perjalanan yang dilakukan oleh seseorang atau sekelompok orang dengan mengunjungi tempat tertentu untuk tujuan rekreasi, pengembangan pribadi, atau mempelajari keunikan daya tarik wisata yang dikunjungi, dalam jangka waktu sementara (Ismayanti, 2010). Pariwisata merupakan berbagai macam kegiatan wisata dan didukung berbagai fasilitas serta layanan yang disediakan oleh masyarakat, pengusaha, dan pemerintah (Ismayanti, 2010). Dalam UU Nomor 10 Tahun 2009 tentang Kepariwisataan, Daya Tarik Wisata adalah segala sesuatu yang memiliki keunikan, keindahan, dan nilai yang berupa keanekaragaman kekayaan alam, budaya, dan hasil buatan manusia yang menjadi sasaran atau tujuan kunjungan wisatawan.

Daya Tarik Wisata dibagi menjadi Daya Tarik Wisata Alam, Daya Tarik Wisata Buatan dan budaya (Kemenpar, 2016). Menurut Suwantoro (2004) daya tarik wisata yang juga disebut objek wisata merupakan potensi yang menjadi pendorong kehadiran wisatawan ke suatu daerah tujuan wisata, teridir dari Pengusahaan Daya Tarik Wisata Alam, Daya Tarik Wisata Budaya Pengusahaan Daya Tarik Wisata Minat Khusus (Ismayanti 2010).

Minat merupakan kekuatan pendorong yang menyebabkan seseorang menaruh perhatian pada orang lain atau pada objek lain. Minat merupakan salah satu sumber motivasi seseorang untuk melakukan kegiatan yang disukai (Kanuk, 2007) yang akan berdampak terhadap peningkatan pangsa pasar. Ada 3 (tiga) faktor yang dapat menimbulkan minat seseorang, yaitu faktor dorongan dari dalam, faktor motif sosial dan faktor emosional.

Lovelock dan Wright (2007), menyebutkan bahwa bauran pemasaran merupakan alat yang dapat digunakan dalam menjalankan strategi peningkatan pangsa pasar yang telah dipilih (baik produk, harga, lokasi atau tempat, maupun 
promosi) dan usaha-usaha lain dalam penyampaian nilai sehingga sesuai dengan keinginan pembeli yang akan dituju. Setidaknya Lovelock dan Wright (2007) menjelaskan bahwasanya terdapat 8 (delapan) komponen dalam sebuah manajemen pelayanan (service) yang dapat berimplikasi dalam meningkatkan pangsa pasar. Elemen-elemen tersebut terbagi dalam kategori berikut: (1) Product Element (Produk), semua komponen dari kinerja layanan yang menciptakan nilai bagi pelanggan. (2) Place (Tempat, cyberspace, dan waktu), keputusan manajemen tentang kapan, di mana, dan bagaimana memberikanlayanan kepada pelanggan. (3) Process (Proses), metode operasi atau serangkaian tindakan yang biasanya melibatkan langkah-langkah yang perlu dilakukan dengan tahapan yang jelas. (4) Productivity and Quality (Produktivitas dan Kualitas), seberapa efisien input layanan diubah menjadi output yang menambah nilai bagi pelanggan. Sedangkan kualitas sendiri sejauh mana layanan memuaskan pelanggan dengan memenuhi kebutuhan mereka, keinginan, dan harapan. (5) People (Orang), pelanggan dan karyawan yang terlibat dalam produksi jasa. (6) Promotion and Education (Promosi dan edukasi), semua kegiatan komunikasi yang insentif dan dirancang untuk membangun preferensi pelanggan untuk layanan tertentu atau sebagai penyedia layanan. (7) Physical evidence (Bukti fisik), petunjuk visual atau berwujud lainnya yang memberikan bukti kualitas layanan. (8) Price and other user outlays (harga dan pengeluaran lainnya), pengeluaran uang, waktu, dan usaha yang pelanggan keluarkan dalam pembelian dan pemakaian jasa tersebut

\section{METODE}

Penelitian ini dilakukan di Kampung Adat Kasepuhan Ciptagelar yang berada di wilayah Dusun Sukamulya, Desa Sirnaresmi, Kecamatan Cisolok, Kabupaten Sukabumi, Jawa Barat. Populasi dalam penelitian ini adalah wisatawan domestik yang berkunjung ke Kampung Adat Kasepuhan Ciptagelar. Metode nonprobability sampling dengan teknik purposive sampling, digunakan dalam penelitian ini. Data responden diperoleh dari buku tamu yang terdapat di Kampung Kasepuhan Ciptagelar. Kriteria yang memenuhi syarat berdasarkan pertimbangan yaitu Wisatawan Domestik (Wisnus) dan mengetahui tentang objek wisata Kampung Adat Kasepuhan Ciptagelar. Pengumpulan data dengan Observasi, 
Wawancara dan Kuisioner Pengujian validitas dan realibilitas dilakukan dengan Cronbach Alpha dan Korelasi Produk Momen Pearson.

Teknik analisis yang digunakan dalam penelitian ini adalah Analisis Faktor Eksploratori. Analisis faktor eksploratori adalah salah satu teknik statistika yang dapat digunakan untuk memberikan deskripsi yang relatif sederhana melalui reduksi sejumlah variable yang disebut faktor serta mengidentifikasi item atau variabel berdasarkan kemiripannya. Analisis faktor adalah analisis yang bertujuan mencari faktor-faktor utama yang paling mempengaruhi variabel dependen dari serangkaian uji yang dilakukan atas serangkaian variabel independen sebagai faktornya.

\section{HASIL DAN PEMBAHASAN}

\section{Hasil}

Uji validitas dimaksudkan untuk mengetahui apakah instrumen tersebut mempunya kevalidan atau kesahihan. Dengan taraf signifikan $(\alpha)$ 0,05 atau 5\% dan $\mathrm{n}=20$, maka $\mathrm{r}$ tabel sebesar 0,444 dapat terlihat ada 2 butir pernyataan yang tidak valid karena memiliki nilai korelasi yang lebih rendah dari nilai $r$ tabel. Diperoleh nilai Cronbach's Alpha sebesar 0,919 yang berarti lebih tinggi dari syarat nilai yang harus dilalui yaitu > 0,6 (pada tabel 1.4). Maka dapat disimpulkan bahwa hasil data dari kuesioner memiliki reabilitas yang baik.

Berdasarkan hasil penyebaran kuesioner yang telah dilakukan dalam penelitian ini, didapatkan responden sebanyak 170 orang yang memenuhi kriteria dalam pengisian kuesioner ini. Terdiri dari aspek demografi, penilaian terhadap daya tarik yang dimiliki Kasepuhan Ciptagelar hingga minat wisatawan untuk berkunjung dan melakukan kunjungan kembali ke Kasepuhan Ciptagelar.

Dalam penelitian ini didominasi oleh laki-laki yaitu sebanyak 98 (58\%). Responden perempuan sebanyak 72 (42\%). Sebagian besar responden adalah usia antara 19-28 tahun. Sebesar 65\% responden yang berusia 19-28, usia 29-38 tahun sebesar 22\%, dan usia 39-49 sebesar 9\%. Sedangkan jumlah terkecil adalah responden yang memiliki usia $<19$ tahun, yaitu hanya 7 (4\%).

Kunjungan wisatawan ke Kasepuhan Ciptagelar didominasi mahasiswa sebesar 41\%, sebesar 16\% Karyawan swasta, 9\% responden Blogger, PNS sebesar 
7\%, diikuti Photographer dan Wiraswasta sebesar 4\%, BUMN dan responden yang tidak bekerja sebesar 3\%. Sedangkan hanya 1\% adalah Reporter dan Ibu Rumah Tangga. Kunjungan Kasepuhan Ciptagelar didominasi oleh wisatawan asal Jawa Barat sebesar 56\% dari 170 responden. Sebesar 33\% kunjungan wisatawan asal DKI Jakarta, diikuti wisatawan asal Banten yaitu sebesar 6\%. Sedangkan kunjungan dari daerah lain seperti Sumatera Utara, Kalimantan Utara, DI Yogyakarta, dan Sulawesi Selatan masing-masing sebesar $1 \%$.

Sebanyak 20 orang dari total responden yang belum pernah mengunjungi Kasepuhan Ciptagelar yaitu sebesar 12\%. Sebanyak 140 orang atau sebesar 82\% responden yang sudah pernah 1 kali berkunjung ke Kasepuhan Ciptagelar. Sedangkan untuk kunjungan berulang 2-4 kali hanya sebesar 6\% atau sebanyak 10 orang. Dapat disimpulkan dari tabel di atas bahwa kunjungan pertama kali mendominasi frekuensi kunjungan wisatawan ke Kasepuhan Ciptagelar yaitu sebesar $82 \%$.

Sebesar 39\% kunjungan pada waktu bisnis atau tugas. sebanyak 46 orang atau sebesar 31\% kunjungan wisatawan ke Kasepuhan Ciptagelar pada saat Seren Taun yang merupakan ritual tahunan masyarakat Kasepuhan. Diikuti 17\% kunjungan dilakukan saat akhir pekan, serta saat tanggal merah atau libur Nasional sebesar $11 \%$. Sedangkan kunjungan paling rendah pada saat cuti kerja yaitu hanya sebesar 2\% dari total responden. Dapat disimpulkan bahwa mayoritas kunjungan dilakukan pada saat bertugas, hal ini cukup wajar mengingat mayoritas pengunjung yang datang ke Kasepuhan Ciptagelar adalah Mahasiswa, yang menjadikan Kasepuhan ini sebagai objek dari tugas mereka.

Kunjungan ulang yang dilakukan wisatawan merupakan bentuk perilaku yang menunjukkan bahwa segala bentuk daya tarik yang dimiliki Kasepuhan Ciptagelar memiliki daya tarik tersendiri yang membuat pengunjung selalu ingin kembali ke Kampung ini. Seluruh responden tertarik dengan segala potensi wisata yang dimiliki Kasepuhan Ciptagelar sehingga berminat untuk berkunjung bagi responden yang belum pernah, dan melakukan kunjungan ulang bagi responden yang sudah berkunjung. Hal tersebut terlihat jelas bahwa dari 170 orang responden, seluruhnya atau sebesar 100\% menjawab "iya" dalam arti berminat untuk 
melakukan kunjungan.

Berdasarkan hasil analisis diperoleh hasil analisis faktor menunjukkan bahwa nilai Kaiser-Meyer-Olkin Measure of Sampling Adequancy didapatkan sebesar 0.883. Hasil analisis ini termasuk pada hasil yang cukup baik mengingat angkat tersebut telah berada diatas nilai 0.5, begitu juga dengan nilai Bartlett's Test of Sphericity mempunyai nilai 707.762 dengan nilai signifikannya sebesar 0.000 yang menjelaskan bahwa analisis faktor ini selain sudah terjadi korelasi yang signifikan.

Nilai anti-image matrics dapat dilihat bahwa angka MSA untuk seluruh variabel sudah memenuhi batas 0.5. Dengan demikian semua variabel-ariabel tersebut dapat dianalisis lanjut atau dapat dinyatakan bahwa semua faktor telah valid atau relevan sehingga mampu mengukur variabel dengan baik.

\section{Tabel 1. Total Variance Explained}

\begin{tabular}{|c|c|c|c|c|c|c|c|c|c|}
\hline \multirow{2}{*}{$\begin{array}{c}\text { Compo } \\
\text { nent }\end{array}$} & \multicolumn{3}{|c|}{ Initial Eigenvalues } & \multicolumn{3}{|c|}{$\begin{array}{c}\text { Extraction Sums of Squared } \\
\text { Loadings }\end{array}$} & \multicolumn{3}{|c|}{$\begin{array}{c}\text { Rotation Sums of Squared } \\
\text { Loadings }\end{array}$} \\
\hline & Total & $\%$ of Var & Cum. \% & Total & $\%$ of Var & Cum \% & Total & $\%$ of Var & Cum. \% \\
\hline 1 & 5.228 & 34.852 & 34.852 & 5.228 & 34.852 & 34.852 & 2.899 & 19.328 & 19.328 \\
\hline 2 & 1.277 & 8.512 & 43.363 & 1.277 & 8.512 & 43.363 & 2.560 & 17.064 & 36.392 \\
\hline 3 & 1.110 & 7.398 & 50.761 & 1.110 & 7.398 & 50.761 & 2.155 & 14.369 & 50.761 \\
\hline 4 & .993 & 6.618 & 57.379 & & & & & & \\
\hline 5 & .902 & 6.015 & 63.394 & & & & & & \\
\hline 6 & .777 & 5.178 & 68.572 & & & & & & \\
\hline 7 & .714 & 4.762 & 73.335 & & & & & & \\
\hline 8 & .641 & 4.272 & 77.606 & & & & & & \\
\hline 9 & .579 & 3.861 & 81.468 & & & & & & \\
\hline 10 & .559 & 3.727 & 85.194 & & & & & & \\
\hline 11 & .510 & 3.399 & 88.593 & & & & & & \\
\hline 12 & 498 & 3.321 & 91.914 & & & & & & \\
\hline 13 & .440 & 2.935 & 94.849 & & & & & & \\
\hline 14 & 402 & 2.678 & 97.527 & & & & & & \\
\hline 15 & .371 & 2.473 & 100.000 & & & & & & \\
\hline
\end{tabular}

Hasil analisis di atas menunjukkan bahwa dari 15 variabel yang dianalisis seluruhnya dapat dikelompokkan menjadi 3 faktor utama. Dapat dilihat dari nilai Eigenvalues yang berada di atas nilai 1 pada kolom komponen pada Tabel 1, yaitu nilai sebesar 5,228, 1,277 dan 1,110. Hasil akhir rotasi menunjukkan bahwa seluruh variabel yang dianalisis membentuk 3 kelompok/ faktor besar, dimana variabel Leuit, kearifan lokal, pakaian adat, upacara adat, kuliner, track offroad, dan track downhill berada pada kelompok pertama. Variabel keindahan, kesejukkan, 
hutan rimba, kesenian, serta ekowisata termasuk kedalam kelompok 2. Variabel lainnya seperti aturan berpakaian, rumah adat, dan situs sejarah termasuk dalam kelompok 3, berikut rinciannya.

Tabel 2 Rotated Component Matrix ${ }^{a}$

\begin{tabular}{|c|c|c|c|c|}
\hline \multirow{2}{*}{ No } & \multirow{2}{*}{ Variabel } & \multicolumn{3}{|c|}{ Component } \\
\hline & & 1 & 2 & 3 \\
\hline 1 & keindahan & ,093 & ,831 & ,031 \\
\hline 2 & kesejukan & 031 &, 560 & ,458 \\
\hline 3 & hutan & 188 & ,685 & 178 \\
\hline 4 & aturan & 147 & ,081 & ,772 \\
\hline 5 & rumah & 193 & ,323 & ,510 \\
\hline 6 & leuit & ,482 & 052 & ,471 \\
\hline 7 & kesenian & 302 & ,453 & 239 \\
\hline 8 & situs & 058 & 216 & 637 \\
\hline 9 & kearifan & ,495 & ,465 & ,257 \\
\hline 10 & pakaian & ,538 & 321 & 270 \\
\hline 11 & upacara & ,656 & 101 & 199 \\
\hline 12 & kuliner & ,578 & ,016 & ,356 \\
\hline 13 & offroad & ,771 & ,142 &,- 066 \\
\hline 14 & ekowisata & ,415 & ,471 & ,249 \\
\hline 15 & downhill & ,635 & ,388 &,- 033 \\
\hline
\end{tabular}

Pengelompokkan variabel-variabel ini disebabkan mereka mempunyai sifat data yang identik dengan vaiabel lainnya, sehingga dengan analisis ini dikelompokkan menjadi satu kelompok tertentu.

Tabel 3 Kelompok faktor baru

\begin{tabular}{clccc}
\hline \multirow{2}{*}{ No } & \multicolumn{1}{c}{ Variabel } & $\mathbf{1}$ & $\begin{array}{c}\text { Kelompok } \\
\mathbf{2}\end{array}$ & $\mathbf{3}$ \\
\hline 1 & Keindahan & & 2 & \\
2 & Kesejukan & & 2 & \\
3 & Hutan & & 2 & 3 \\
4 & Aturan & 1 & & 3 \\
5 & Rumah adat & & \\
6 & Leuit & & & \\
7 & Kesenian & 1 & & \\
8 & Situs & 1 & & \\
9 & Kearifan lokal & 1 & & \\
10 & Pakaian adat & 1 & & \\
11 & Upacara adat & 1 & & \\
12 & Kuliner & & & \\
13 & Offroad & 1 & & \\
14 & Ekowisata & & & \\
15 & Downhill & & & \\
\hline
\end{tabular}

Sumber : data olahan

Berdasarkan analisis sebelumnya, seluruh variabel yang dianalisis membentuk 3 kelompok atau faktor besar yang telah tersaji pada Tabel 3. Faktorfaktor baru yang terbentuk berdasarkan sifat atau karakteristik data yang identik dengan vaiabel lainnya. Penamaan faktor-faktor baru yang mempengaruhi minat 
berkunjung wisatawan ke Kasepuhan Ciptagelar sebagai berikut.

1) Kelompok 1 dinamakan Faktor Petualangan dan Budaya, yang terdiri dari variabel Leuit, Kearifan lokal, Pakaian adat, Kuliner, jalur Offroad dan jalur Downhill.

2) Kelompok 2 dinamakan Faktor Daya Tarik Wisata dan Keindahan Alam, yang terdiri dari variabel Keindahan alam, Kesejukan, Hutan rimba, Kesenian tradisional, dan Ekowisata.

3) Kelompok 3 dinamakan Faktor Nilai Pranata Sosial dan Sejarah, yang terdiri dari variabel Aturan, Rumah adat, dan Situs sejarah.

Ketiga faktor tersebut berdasarkan besar nilai extraction loading yang menunjukkan bahwa variabel membentuk tiga kelompok besar yang memiliki nilai di atas 0.00 dimana faktor pertama memiliki nilai sebesar 5.228 diikuti faktor kedua dengan nilai sebesar 1.277 dan faktor ketiga sebesar 1.110. Hal tersebut berarti faktor pertama memiliki pengaruh yang paling besar dalam mempengaruhi minat berkunjung wisatawan ke Kasepuhan Ciptagelar diikuti pada faktor kedua dan ketiga.

Dari faktor-faktor baru yang terbentuk, dapat dilihat bagaimana korelasi antara faktor-faktor dengan minat berkunjung pada Tabel 4. Berdasarkan Tabel 4, dari ketiga faktor tersebut faktor 1 dan 3 memiliki nilai korelasi antar faktor yang kuat karena memiliki nilai korelasi diatas 0,5 yaitu 0,641 dan 0,705. Sedangkan pada faktor 2 memiliki korelasi yang lemah karena memiliki nilai $<0,5$ yaitu sebesar 0,402. Dapat diartikan bahwa Faktor Petualangan dan Budaya serta Faktor Pranata Sosial dan Nilai Sejarah sudah tepat sebagai faktor yang dapat meningkatkan pangsa pasar wisatawan domestik. Sedangkan Faktor Keindahan Alam belum tepat dikarenakan faktor tersebut memiliki korelasi dengan faktor lainnya yang tidak diteliti dalam penelitian ini.

Tabel 4 Component Transformation Matrix

\begin{tabular}{cccc}
\hline Component & 1 & 2 & 3 \\
\hline 1 & $\mathbf{6 4 1}$ & $\mathbf{, 5 8 8}$ &, 493 \\
2 &,- 761 & $\mathbf{, 4 0 2}$ &, 510 \\
3 &, 101 &,- 702 & $\mathbf{, 7 0 5}$ \\
\hline
\end{tabular}

Extraction Method: Principal Component Analysis.

Rotation Method: Varimax with Kaiser Normalization. 


\section{Pembahasan}

Kasepuhan Ciptagelar merupakan salah satu dari Komunitas Adat Banten Kidul yang terlekat di Gunung Halimun. Secara Administratif Kasepuhan Ciptagelar berada di wilayah Taman Nasional Gunung Halimun Salak (TNGHS), Dusun Sukamulya Desa Sirnaresmi, Kecamatan Cisolok, Kabupaten Sukabumi Jawa Barat. Jarak Kampung Ciptagelar dari Desa Sirnaresmi 14 km, 44 km dari Pelabuhan Ratu kearah Cisolok, dan sekitar 200 kilometer dari Jakarta. "Saat ini Kasepuhan Ciptagelar dihuni oleh 499 orang yang terdiri dari 125 kepala keluarga yakni 250 orang laki-laki dan 249 orang perempuan setelah mendapat tambahan penduduk dari Kampung Kaununggal pada tahun 2014 sebanyak 125 orang”. Hal ini disampaikan olehBapak Rukanda selaku ketua RT Kampung Ciptagelar.

Kasepuhan Ciptagelar masih memegang kuat adat dan tradisi yang diturunkan sejak 646 tahun yang lalu. Kasepuhan ini dipimpin oleh seorang Abah yang diangkat berdasarkan keturunan hingga saat ini Kasepuhan Ciptagelar sedang dipimpin oleh seorang Abah yang merupakan generasi ke sebelas sejak tercatatnya kasepuhan ini dari tahun 1368. Kasepuhan Ciptagelar pertama kali berdiri di Bogor. Tempat tinggal Kasepuhan selalu berpindah- pindah dari tempat satu ke tempat lain. Perpindahan tersebut dikarenakan datangnya wangsit dari leluhur kepada Abah (pemimpin Kasepuhan).

Pada akhir tahun 2000 Abah Anom (Alm. Encup Sucipta) sebagai pimpinan Kasepuhan pada saat itu menerima wangsit (perintah) dari leluhur untuk pindah dari Kampung Ciptarasa ke Kampung Ciptagelar. Ciptagelar artinya terbuka atau pasrah menerima perpindahan tersebut. Wangsit ini diterima oleh Alm. Abah Anom setelah melalui proses ritual beliau yang hasilnya tidak boleh tidak, mesti dilakukan. Oleh karena itu perpindahan Kampung Adat merupakan kesetiaan dan kepatuhan kepada para leluhur. Setelah sekitar 8 bulan proses pembangunan di Kampung Ciptagelar selesai pada tahun 2001 seluruh masyarakat adat dibawah pimpinan Abah Anom berpindah dari Ciptarasa ke Ciptagelar (nama saat ini). Pada tahun 2007 Abah Anom meninggal dunia dan Kasepuhan Ciptagelar dilanjutkan oleh anaknya yaitu Abah Ugi Sugriana Rakasiwi hingga sekarang (Kasepuhan Ciptagelar, 2008). 
Kasepuhan Ciptagelar merupakan kampung yang masih kental dengan adat dan budaya dari leluhur. Segala kegiatan dalam keseharian mereka tak lepas dari adat yang mereka pegang selama 646 tahun. Kampung ini kaya budaya, adat istiadat, kesenian tradisonal dan keraifan lokal, selain itu alamnya yang indah dan asri. Bahasa yang digunakan di kampung ini ialah bahasa sunda.

Kasepuhan Ciptagelar merupakan pusat pemerintahan dari Kesatuan Adat Banten Kidul yang tersebar di 3 Kabupaten yaitu Bogor, Sukabumi, dan Banten. Terdiri dari 568 kampung kecil dalam 360 kampung besar, kampung-kampung adat ini dikepalai oleh seorang kepala adat (Sesepuh Lembur) yang berkordinasi langsung dengan Abah Ugi dalam segala hal. Kampung adat tersebut diantaranya Kp. Babakan Simpang; Kp. Lebak Pitung; Kp. Sukamulya; Kp. Limus Nunggal; Kp. Babakan Lengkob; Kp. Cipulus; Kp. Neglarasa; Kp. Cihandam; Kp. Cikuluwung; Kp. Situmurni 1; Kp. Situmurni 2; serta Kp. Babakan Cisuren.

Di Kasepuhan Ciptagelar sebenarnya beragama Islam, namun unsur animisme dan dinamisme masih sangat kental Sangat terlihat pada saat adanya ritual atau upacara-upacara adat dan masih percaya kepada hal-hal magis yang dipecayainya turun menurun dari leluhur. Sebagai perangkat nilai yang dimiliki masyarakat dalam memandang dan memanfaatkan lingkungan banyak dipengaruhi oleh adat istiadat dan lingkungan dimana mereka tinggal, contoh pemahaman masyarakat akan sistem pertanian yang menyelaraskan dengan alam dan tidak mau menanam padi jenis unggul versi pemerintah.

Pengetahuan tentang hutan di masyarakat adat Kasepuhan dibagi 3 golongan, yaitu: (1) Hutan Tua (Leuweung Kolot), yaitu Hutan asli dengan kerimbunan dan kerapatan tinggi serta banyak satwa, tidak boleh dieksploitasi. (2) Hutan Titipan / Kramat (Leuweung Titipan), yaitu Hutan Kramat yang harus dijaga oleh setiap orang dan tidak boleh digunakan tanpa seijin sesepuh girang, memungkinkan diguanakan hasil hutannya bila ada wangsit dari leluhur. (3) Hutan Sempalan / Bukaan (Leuweung Sampalan), yaitu Hutan Bukaan yang boleh dieksploitasi untuk ladang, menggembalakan ternak, mencari kayu bakar dan ditanami berbagai tanaman kayu dan buah-buahan yang hasilnya bisa dimanfaatkan oleh masyarakat. 
Kasepuhan Ciptagelar terkenal dengan tradisi pertaniannya yang kental dengan adat hingga setiap proses mulai dari penanaman padi hingga panen padi dan merasakan hasil panen tersebut tidak lepas dengan ritual adat setempat. Ritual prosesi adat penanaman padi di Kasepuhan Ciptagelar yaitu Ritual Ngaseuk, Ritual Sapang Jadian Pare, Ritual Pare Ngidam Mapag Pare Beukah, Ritual Sawenan, Ritual Mipit Pare, Ritual Nganyaran / Nutup Pare Anyar, Ritual Ngabukti Nyangu Pare Anyar, dan Ritual Ponggokan.

Sementara itu, Ritual Seren Taun adalah acara puncak dari segala kegiatan masyarakat Kasepuhan yang dilakukan hanya di kampung gede setiap tahunnya. Upacara besar dalam menghormati leluhur dan Dewi Sri, dengan berbagai bentuk kesenian dari yang sangat lama hingga seni modern sekalipun ditampilkan untuk masyarakat, dan padi dibawa dan diarak, diiringi oleh semua orang untuk kemudian disimpah di Leuit Si Jimat. Selain upacara adat yang terkait dengan proses penanaman padi, upacara lain yang dilakukan masyarakat selamatan empat belasan, Upacara Nyawen bulan Safar, Selamatan Rosulan dan Sedekah Maulud dan Ruwah.

Sebagian besar masyarakat Kasepuhan bermata pencaharian sebagai petani karena Kasepuhan Ciptagelar merupakan kampung adat yang sarat akan tradisi pertaniannya yang marupakan titipan dari leluhur atas untuk mempertahankan pertanian. Berbeda dengan panen padi pada umumnya, di Kasepuhan ini panen padi hanya dilakukan sekali dalam setahun. Sistem penanaman lahan pun memiliki aturan, yaitu lahan digunakan untuk penanaman padi sekali dalam setahun dan diselingi dengan menanam sayuran agar unsur hara di dalam tanah tidak rusak dan kembali netral.

Masuknya peralatan modern ke Kampung ini tidak menghilangkan tradisi lama dari nenek moyang mereka terutama dalam bidang pengetahuan pertanian. Tradisi bertanam mereka masih memegang tradisi leluhur. Tanpa obat-obatan kimiawi dan selalu berhasil panen setiap tahun. Dengan memberikan kesempatan untuk bernapas sejenak kepada bumi yang menghidupkan padi-padian maka yang terjadi adalah panen yang selalu berhasil dan leuit-leuit (tempat penympanan padi) yang tidak pernah diserang hama. Hingga bidang kesehatan pun warga Ciptagelar menggunakan obat-obatan tradisional racikan asli warga yang berasal dari tumbuh- 
tumbuhan yang berada di sekitar perkampungan.

Secara pergaulan, warga Kasepuhan kini terbuka dengan pendatang, ramah, dan supel sekalipun baru bertemu dengan pendatang. Keramahan dan sambutan hangat ditengah keseharian warga yang sering membuat para pendatang merasa betah selama berada di Kampung ini. Bahkan tak sedikit pendatang atau wisatawan yang kagum dan heran bagaimana bisa mereka selalu berkecukupan tertama untuk setiap pendanaan ritual adat yang tidak murah, padahal mereka hidup secara sederhana, bahkan mereka tidak menerima gaji karena hasil pertaniannya pun tidak dijual ke luar.

Berada di dalam kawasan ekowisata Taman Nasional Gunung Halimun Salak (TNGHS) , tak hanya memiliki kawasan berbasis budaya, kawasan ini juga memiliki ragam daya tarik lain diantaranya terdapat jalur wisata hiking atau Trecking menuju Situ Legok Tonggoh dan Situ Legok Lebak yang terdapat di Gn. Sangiang yang berada di 1.600 mdpl. Lokasi tesebut dapat ditempuh melalui 4 jalur pendakian yaitu melalui Kp. Cisarua, Balai Desa Sirnarasa, Kp. Sirnarasa, dan Situs Genter Bumi. Perjalanan melewati hutan lebat juga dilalui dengan jalur yang menantang, sering dijadikan untuk track downhill karena jalurnya yang turunan dan tanjakan yang curam.

Hutan lebat menuju Kasepuhan Ciptagelar juga menyimpan banyak aneka flora dan fauna. Pada umumnya makanan khas di Kampung Gede seperti daerah tataran Sunda pada umumnya. Dicirikan dengan ikan asin, sambal terasi dan lalapan yang dimasak dari tungku dari batu cadas serta menggunakan kayu bakar sehingga cita rasa yang dihasilkan sangat khas. Makanan lain yang sering dibuat khususnya jika ada upacara adat yaitu dodol, wajit, opak. Keunikan dari panganan khas buatan masyarakat Kasepuhan, proses pembuatan kue-kue di Kasepuhan ini terbuat dari tepung yang dibuat bersama-sama dari hasil kegiatan tiap bulan masyarakat yang dikenal Nipung ka halu. Sebuah proses pembuatan tepung untuk kue dengan cara tradisional Hasil dari tepung ini yang dijadikan macam-macam panganan khas Ciptagelar mulai dari dodol, wajit, dan kue lainnya. Gula dalam pembuatan dodol dan wajit pun terbuat dari gula aren buatan masyarakat dengan cara tradisional dan jauh dari pengawet. 
Menjaga kekentalan adat dari leluhur selama turun temurun menjadikan Kasepuhan Ciptagelar mulai didatangi banyak wisatawan yang ingin merasakan kearifan budaya lokal masyarakat Kasepuhan. Hal tersebut menjadi daya tarik tersendiri bagi wisatawan yang berkunjung ke Kasepuhan. Dan kini informasi tentang Kasepuhan sudah makin mudah didapat karena makin banyak yang mengangkat keunikan budaya Kasepuhan ini di sosial media dan Internet. Tak hanya keindahan alam yang dari atas pegunungan, Kasepuhan Ciptagelar juga memiliki banyak keunikan dari budaya yang mereka pegang teguh, hingga kehidupan masyarakat yang ramah dan penuh kekeluargaan memberikan suasana nyaman kepada wisatawan yang datang.

Tak hanya itu, wisatawan pun dibuat terpesona dengan perkembangan dari Kasepuhan Ciptagelar dari segi teknologi, karena teknologi yang ada di Kasepuhan ini hasil buatan tangan masyarakat sendiri. Namun ditengah perkembangan zaman kini, tidak mengubah adat istiadat Kasepuhan. Mereka tetap sederhana dan berlaku secara adat. Hal tersebut juga menjadi harapan dari wisatawan yang datang, bahwa Kasepuhan dapat menjaga kekentalan adatnya ditengah perkembangan zaman dan Globalisasi.

Sebagaimana laiknya suatu objek wisata pada umumnya, pengelola objek wisata pun harus memerhatikan aspek bauran pemasaran. Dhiba dan Maduwinarti (2014); Kristiutami (2015); Areks, dkk (2015) menyatakan bahwa faktor-faktor bauran pemasaran seperti: produk, harga, promosi dan lokasi akan sangat berpengaruh terhadap minat kunjungan wisatawan. Pengelola objek wisata harus memerhatikan pula aspek pelayanan dan keamanan kepada para wisatawan. Hal ini agar wisatawan bisa merasa nyaman, aman, dan peduli akan lingkungan alam bebas (Sondakh dan Tumbel, 2016).

Olivia, dkk (2015) menyimpulkan bahwa lingkungan eksternal yang berupa faktor budaya, kelas sosial, referensi, dan keluarga akan memengaruhi keputusan berkunjung wisatawan. Hal serupa ditemukan pula oleh Hermansyah dan Waluya (2012). Produk yang dijual pada Kasepuhan Ciptagelar ialah berpusat pada produk ekowisata yang berbasis kepada budaya dan alam. Hal ini menjadi faktor penentu dalam keputusan berkunjung wisatawan. Kirom, dkk (2016) menerangkan 
pula bahwa faktor budaya merupakan salah satu faktor penentu daya tarik wisata. Hal lain yang harus ditekankan ialah faktor promosi. Ginting (2016) menyatakan bahwa faktor promosi menjadi salah satu faktor dalam meningkatkan kunjungan wisatawan.

\section{SIMPULAN}

Ketertarikan wisatawan terhadap daya tarik wisata yang dimiliki Kasepuhan Ciptagelar digambarkan dengan nilai Kaiser-Meyer-Olkin Measure of Sampling Adequancy sebesar 0.883, nilai signifikan 0.5. Nilai Bartlett's Test of Sphericity sebesar 707.762 dengan signifikansi sebesar 0.000 menunjukkan bahwa analisis faktor ini, selain sudah terjadi korelasi yang signifikan dengan terbentuknya 3 faktor baru yang dapat meningkatkan pangsa pasar wisatawan. Faktor-faktor tersebut adalah: (1) Faktor Petualangan dan Budaya dengan nilai eigenvalues sebesar 5.228, terdiri dari variabel Leuit, Kearifan lokal, Pakaian adat, Kuliner, jalur Offroad dan jalur Downhill. (2) Faktor Daya Tarik Wisata dan Keindahan Alam dengan nilai eigenvalues sebesar 1.277, terdiri dari variabel Keindahan alam, Kesejukan, Hutan rimba, Kesenian tradisional dan Ekowisata. (3) Faktor Nilai Pranata Sosial dan Sejarah dengan nilai eigenvalues sebesar 1.110, terdiri dari variabel Aturan, Rumah adat, dan Situs sejarah.

Dari ketiga faktor yang terbentuk hanya faktor 1 dan 3 saja yang sudah tepat disebut sebagai faktor yang dapat meningkatkan pangsa pasar wisatawan hal ini dikarenakan kedua faktor tersebut memiliki nilai korelasi antar faktor diatas 0.5 yaitu 0.641 dan 0.705. Sedangkan pada faktor 2 yang memiliki nilai korelasi antar faktor lebih kecil dari 0.5 yaitu 0.402 dikatakan belum tepat dikarenakan faktor ini masih memiliki korelasi dengan variable lainnya yang tidak diteliti dalam penelitian ini.

\section{PUSTAKA ACUAN}

Areks, E., M. Nadjib, \& S. Canggara. (2015). Pengaruh Pengguna Bauran Promosi Terhadap Tingkat Kunjungan Wisatawan Pada Objek Wisata Alam di Kabupaten Pangkajene dan Kepulauan. Jurnal Komunikasi KAREBA. Vol. 4 (4): $360-374$. 
Dhiba, I.D.S. \& A. Maduwinarti. (2014). Analisis Pengaruh Bauran Pemasaran Jasa Terhadap Minat Pengunjung Pada Obyek Wisata Museum Kesehatan Dr. Adhyatama, MPH Surabaya. Jurnal Ilmu Ekonomi dan Manajemen. Vol. 1 (1): 94-109.

Ginting, N. (2016). Strategi Pemasaran Untuk Meningkatkan Jumlah Kunjungan Wisatawan. Analisis Ekonomi Utama. Vol. X (2): 89-98.

Hermansyah, D. \& B. Waluya. (2012). Analisis Faktor-faktor Pendorong Motivasi Wisatawan Nusantara Terhadap Keputusan Berkunjung Ke Kebun Raya Bogor. Tourism and Hospitality Essentials Journal. Vol. II (1): 245-268.

Ismayanti. (2010). Pengantar Pariwisata. Jakarta: Grasindo.

Kirom, N.R., Sudarmiatin, \& I.W.J.A. Putra. (2016). Faktor-faktor Penentu Daya Tarik Wisata Budaya dan Pengaruhnya Terhadap Kepuasan Wisatawan. Jurnal Pendidikan. Vol. 1 (3): 536-546.

Kristiutami, Y.P. (2015). Pengaruh Bauran Pemasaran Terhadap Keputusan Berkunjung Wisatawan di Museum Geologi Bandung. Pariwisata, Vol. II (2): 77-89.

Lovelock, C., \& L.K. Wright. (2007). Manajemen Pemasaran Jasa. Jakarta: PT. Indeks Gramedia.

Olivia, D.F., M. Saifi., \& M.G. W. Endang N.P. (2015). Pengaruh Faktor-faktor Lingkungan Eksternal Terhadap Keputusan Berkunjung Wisatawan (Studi Pada Wisatawan Museum Angkut Batu Jawa Timur). Jurnal Administrasi Bisnis. Vol. 21 (1): 1-10.

Sondakh, P.M.N., \& A. Tumbel. (2016). Pelayanan, Keamanan dan Daya Tarik Mempengaruhi Minat Wisatawan yang Berkunjung ke Objek Wisata Alam Gunung Mahawu, Tomohon. Jurnal Berkala Ilmiah Efisiensi. Vol 16 (1): 280288. 